\title{
Pemikiran kalam K.H.M. Zen Syukri dan relevansinya terhadap kondisi sosiologi masyarakat \\ Kota palembang pada tahun 1962-2012 (telaah terhadap buku risalatut tauhid)
}

\author{
Nur Ramadhon, J. Suyuthi Pulungan, Mohammad Syawaludin \\ Fakultas Adab Dan Humaniora UIN Raden Fatah Palembang \\ Email: romadhon.palembang@gmail.com
}

\begin{abstract}
Abstrak
Islam merupakan agama rohmatan lil alamin, yang membawa perdamaian, cinta kasih, kemanusiaan, dan menebarkan keselamatan bagi insan sekalian alam. Namun, agama kehilangan sentuhan kemanusiaannya ketika berbagai konflik sosial seringkali muncul akibat krisis keagamaan. Hal ini disebabkan ada kesenjangan yang cukup dalam antara aspek normativitas dan historisitas dari agama itu sendiri. Krisis keagamaan ini muncul disebabkan adanya klaim kebenaran (truth claim) atas tafsir keagamaan yang sepihak serta kuatnya sikap eksklusif dalam beragama. Kondisi tersisih akibat dari klaim kebenaran itu pernah dialami oleh K.H.M. Zen Syukri (kyai dan ulama kota Palembang) ketika ajaran keagamaan beliau mendapatkan resistensi dari sebahagian kyai dan ulama kota Palembang bahkan kasus tersebut sampai naik ke meja hijau, meskipun pada akhirnya pengadilan menyatakan bahwa ajaran K.H.M. Zen Syukri bukan ajaran sesat
\end{abstract}

Kata kunci: pemikiran kalam, M. Zen sukri, sosiologi, palembang

\begin{abstract}
Islam is religion of rohmatan lil alamin, which brings peace, love, humanity, an spreading salvation for all people of nature. However, religion loses its human touch when various social conflicts often arise due to religious crises. This is because there is a considerable gap in the aspects of normativity and the historicity of religion itself. This religious crisis arises due to the existence of truth claim on unilateral religious interpretation and the strength of an exclusive attitude to religion. Condition of exclusion resulting from claims of truth have been experienced by K.H.M. Zen Syukri (kyai and Palembang city cleric) whwn his religious teaching got resistance from some kyai and cleric of the city of Palembang even the case reached the court, although in the end the court stated that the teachings of K.H.M. Zen Syukri is not heresy
\end{abstract}

Key word: mind of kalam, $m$. Zen syukri, sociology, palembang

\section{A. PENDAHULUAN}

K.H.M. Zen Syukri adalah tokoh ulama kharismatik yang semasa hidupnya sebagai da'i dan ulama dikenal luas oleh masyarakat Sumatera Selatan khususnya di kota Palembang. Beliau lahir pada hari Senin subuh tanggal, 10 Oktober 1919 M. Dan wafat pada hari Kamis Tanggal, 22 Maret 2012. Pada masa hidupnya hampir seluruh lapisan masyarakat khususnya umat Islam di kota Palembang mengenal sosok K.H.Muhammad Zen Syukri (selanjutnya ditulis M. Zen Syukri). 
Meskipun demikian kisah sukses M. Zen Syukri sebagai ulama sekaligus sebagai tokoh masyarakat bukanlah tanpa aral melintang. Dalam perjalanan karirnya sebagai ulama, M. Zen Syukri beberapa kali menghadapi persoalan yang cukup berat di dalam berdakwah, menyampaikan ajaran Islam. Namun semua itu beliau hadapi dengan sabar dan tawakal kepada Allah swt. sehingga setiap permasalahan yang datang dapat diselesaikan secara baik. Salah satu persoalan yang beliau hadapi semasa hidup sebagai da'i dan ulama adalah mengenai resistensi (penolakan) sebahagian alim ulama kota Palembang terhadap pemikirannya yang dituangkan di dalam sebuah karya tulis yang berjudul "Risalatut Tauhid". Sebuah buku teks ajaran Islam yang naskah aslinya ditulis dengan menggunakan huruf Arab melayu, yang memaparkan pemikiran M. Zen Syukri tentang persoalan tauhid atau kalam, sebagai ajaran pokok di dalam agama Islam. Bahwa tauhid pada hakekatnya bukan hanya menafikan sembahan lain selain Allah SWT, tetapi lebih dari itu pada kajian yang lebih mendalam kalimat Laa ilaha illa Allah (kesaksian bahwa tidak ada tuhan selain Allah swt) memiliki makna yang luas.

Hal yang patut disayangkan, perbedaan pendapat keagamaan (dalam hal ini dalam bidang kalam) yang seharusnya diterima sebagai sebuah rahmat dan kekayaan intelektual direspon dengan sikap saling menyesatkan dan pemboikotan, yang dalam kasus M. Zen Syukri ini bahkan sampai naik ke meja hijau, meskipun di dalam persidangan baik pengadilan tingkat daerah maupun tingkat pusat majelis hakim menetapkan bahwa ajaran M. Zen Syukri bukan ajaran sesat sehingga sehingga M. Zen Syukri boleh terus menyampaikan ajaran Islam, faham keagamaannya. ${ }^{1}$ Dan secara hukum buku "Risalatut Tauhid" karyaM. Zen Syukri tersebut kemudian telah disyahkan oleh Kementerian Agama Nomor: K/1152/52/831/62.

Suatu hal yang menarik, setelah kasus kontroversial mengenai pemikiran kalam M. Zen Syukri yang beliau paparkan di dalam buku yang berjudul "Risalatut Tauhid" tersebut selesai, animo masyarakat (khususnya umat Islam) di kota Palembang justeru meningkat untuk mengetahui apa dan bagaimana sesungguhnya ajaran ilmu kalam (tauhid) yang disampaikan di dalam buku itu. Maka berlomba-lombalah masyarakat kota Palembang pada waktu itu untuk membeli dan mengkaji buku tersebut. Sehingga buku yang memuat pemikiran M. Zen Syukri tentang tauhid itu sampai tiga kali naik cetak. Hal ini tentu saja selain berdampak ekonomis terhadap pribadi dan aktifitas dakwah M. Zen Syukri, juga mengakibatkan penyebaran ajaran keislaman M. Zen Syukri yang semakin meluas.

Berdasarkan beberapa uraian di atas peneliti tertarik untuk mengkaji pemikiran kalam atau

${ }^{1}$ https://cendikiasumsel wordpress.com 
dalam istilah lain disebut sebagai "pemikiran tauhid" M. Zen Syukri. Kategori atau corak pemikiran kalam M. Zen Sukri di dalam kajian ilmu kalam klasik, faktor-faktor sosial apa yang berperan terhadap munculnya resistensi terhadap pemikiran kalam M. Zen Syukri dan bagaimana relevansi pemikiran kalam M. Zen Syukri terhadap kondisi sosiologis masyarakat kota Palembang pada saat itu sehingga pemikiran kalam M. Zen Syukri tersebut pada akhirnya mendapatkan apresiasi yang cukup baik di tengah masyarakat kota Palembang. Karena menurut hemat peneliti pokok persoalan yang terjadi dalam kasus resistensi pemikiran keagamaan M. Zen Syukri sejak beliau mengemukakan pemikiran keagamaannya melalui buku yang berjudul "Risalatut Tauhid" pada hakikatnya adalah merupakan polemik (dan seringkali berujung konflik) yang telah terjadi sejak ratusan ribu tahun yang silam dalam khazanah pemikiran Islam (khususnya dalam hal ini adalah pemikiran dalam bidang kalam) dan terus berulang dalam konteks waktu dan tempat yang berbeda.

\section{B. METODE PENELITIAN}

Penelitian ini menggunakan metode deskriptif kualitatif dengan pendekatan sosiologi agama. Secara garis besar yang dimaksud dengan penelitian kualitatif yaitu penelitian yang bermaksud untuk memahami fenomena tentang apa yang dialami oleh subjek penelitian secara holistik, dan menguraikannya dengan cara deskripsi dalam bentuk kata-kata dan bahasa, pada suatu konteks khusus yang alamiah dan dengan memanfaatkan berbagai metode ilmiah. ${ }^{2}$

Penelitian dilakukan antara bulan November 2018 sampai dengan bulan Juli 2019. Teknik Pengumpulan data pada penelitian ini merujuk kepada teknik pengumpulan data pada penelitian kualitatif, yakni wawancara mendalam, riset partisipatif, pengamatan dan studi pustaka. Prinsipnya pengumpulan data-data tersebut digunakan untuk menggambarkan fenomena sosial secara alamiah. ${ }^{3}$ Sedangkan teknik analisis data yang digunakan adalah teknik analisis data deskriptif kualitatif, yaitu ${ }^{4}$ : reduksi data, display data, manipulasi data dan content analysisi (analisis isi)

\footnotetext{
${ }^{2}$ Suharsimi Arikunto, Prosedur Penelitian (Suatu Pendekatan Praktik), Jakarta: PT. Rineka Cipta, 2010, hal. 20-30

${ }^{3}$ M Sayuthi Ali, Metodologi Penelitian Agama: Pendekatan Teori Dan Praktek, Jakarta: PT. RajaGrafindo, 2002 , hal. 63

${ }^{4}$ Moh Nazir, Metodologi Penelitian, Jakarta: Ghalia Indonesia, 2005, hal.419
} 
Tamaddun: Jurnal Kebudayaan dan Sastra Islam, Vol. XVIII No. 2, 2018 |

\section{HASIL DAN PEMBAHASAN}

\section{Kondisi Sosial Keagamaan Masyarakat Kota Palembang}

Latar belakang keagamaan di Palembang hingga tahun 1990-an berawal dari sejarah masuknya Islam ke Palembang. Hal ini perlu diungkapkan sebagai bagian untuk mengetahui keadaan keberagamaan masyarakat pada periode ini, Kondisi dan corak keagamaan (islam) di Indonesia yang beraneka ragam tidak terlepas dari sejarah masuknya Islam ke Indonesia. Sebahagian ahli sejarah mengatakan masuknya Islam pada abad ke 7 M melalui para pedagang muslim dari Timur Tengah, terutama Arab dan Persia. Pada saat kedatangan mereka Palembang merupakan pusat kerajaan Sriwijaya masih berdiri kokoh. Catatan sejarah lainnya mengatakan bahwa pengajaran agama Islam di Sumatera Selatan sekitar Abad ke-15 M, ketika Palembang yang dipimpin oleh Raden Fatah masih menjadi wilayah protektorat kerajaan Mataram. Keadaan ini berlanjut sampai ke masa kesultanan Palembang pada abad ke-18. Beberapa data sejarah mengatakan bahwa adanya peran keraton (Sultan) Palembang dalam memberikan sponsor kepada para ulama dalam menulis karya-karya keagamaan yang menghasilkan ratusan kitab dalam bidang keilmuan Islam (Tauhid, Tasawuf, fikih, tarikh Al-Quran, dll).

Islam yang pertama kali ke Indonesia adalah versi sufisme. Pendapat ini, merupakan pendapat umum para sarjana Barat dan pendapat yang belum pernah dibantah oleh orang Indonesia sendiri. Tesis ini berdasarkan alasan, bahwa dakwah Islam sesudah abad ke-2 Hijriyah terus mengalami kemunduran, dan baru dalam abad ke-7 Hijriyah (13 Masehi) aktif kembali akibat sumbangan dakwah dari ahli tasawuf dan ahli tarekat. Proses islamisasi Asia Tenggara berbarengan dengan masa merebaknya tasawuf abad pertengahan dan pertumbuhan tarekat. Tentunya, perjalanan Islam ke Indonesia melalui Persia dan anak benua India ketika itu dicatat sangat berorientasi pada tasawuf. Kitab-kitab yang berhasil menggabungkan fikih dengan amalanamalan akhlak merupakan pelajaran utama di pesantren-pesantren, pada masa-masa sesudahnya. Marrison dalam artikelnya yang berjudul "Coming of Islam in East Indies" mengatakan bahwa Islam masuk ke Indonesia dibawa oleh para mubaligh yang berasal dari India Selatan yaitu Mu'tabar (Malabat) pada Abad ke-13. Gelar fakir mengingatkan pada gelar yang diberikan kepada seorang sufi. ${ }^{5}$

Persantren, sebagai media pengajaran dan pembelajaran agama Islam yang telah berkembang sejak zaman wali songo pun tidak dapat dipisahkan dengan tasawuf. Seluruh sejarah pesantren, baik dalam bentuk "pertapaan" maupun dalam bentuk pesantren abad ke-19 Masehi, sudah memasukkan tasawuf sebagai materi yang diajarkan kepada para santrinya. Sejak pesantren

${ }^{5}$ G.E. Marrison, The Coming of Islam to the east Indies, JBRAS Vol. 24, no. 1 (1951), hlm. 31-36 
itu ada, tasawuf telah diajarkan. Berbeda dengan materi ushul fiqh yang baru muncul belakangan (tahun 1880 M.) dalam kurikulum pesantren, yakni sejak meluasnya lulusan Haramayn yang menguasai bidang tersebut. ${ }^{6}$ Sejak abad ke-16 Masehi di pesantren-pesantren telah diajarkan kitabkitab tasawuf seperti: Ihya' Ulum al-Din, Bidayat al-Hidayah, Talkish al-Minhaj, Syar fi alDaqaiq, al-Kanz al-Khafi, dan Ma'rifat 'Alam. Disamping itu juga, meskipun agak terbatas dipelajari juga karya-karya tentang wadat al-Wujud dan al-Insan al-Kamil karya al-Jiyli. ${ }^{7}$ Bahkan, kitab karya Ibnu 'Athoillah al-Sakandari (w. 796 H./1394 M.) yakni al-Hikam dan Hidayat alAtqiya ila Thariq al-Awliya karya Zain al-Din al-Malibari (w. 914 M./1508 M.). ${ }^{8}$

Sejak Abad ke-20 gerakan pembaharuan di dunia Islam muncul secara besar-besaran. Hal ini ditandai dengan munculnya tokoh-tokoh muslim ataupun organisasi Islam terkemuka di berbagai negara seperti Mesir, India (Pakistan), Arab Saudi, dan lain sebagainya. Gerakan pembaharuan tersebut dimunculkan melalui berbagai istilah yang beragam, antara lain tajdid (renewal, pembaharuan), purifikasi (pemurnian), revivalisme (kebangkitan Islam), dll. Gerakan modernisasi yang berkembang di berbagai tempat khususnya di kawasan Timur Tengah tersebut telah memberikan pengaruh besar kepada gerakan kebangkitan Islam di Indonesia. Ide gerakan pembaharuan tersebut masuk ke Indonesia melalui berbagai saluran, antaranya lewat kontak para intelektual muslim Indonesia dengan intelektual muslim Timur Tengah, dan kontak jemaah haji Indonesia dengan jemaah luar. ${ }^{9}$

Secara umum kelahiran dan perkembangan gerakan pembaharuan Islam tersebut merupakan wujud respon terhadap keadaan atau hal-hal sebagai berikut: ${ }^{10}$ a. Kemunduran Islam sebagai agama akibat praktik-praktik keagamaan yang menyimpang b. Keterjajahan, negaranegara Islam baik secara politik, ekonomi, sosial budaya, oleh dunia barat. c. Kondisi umat Islam yang miskin, kumuh, bodoh, dan terbelakang di banding negara atau bangsa lainnya yang ada di muka bumi. Gerakan pembaharuan ini akhirnya menyebar luas ke berbagai belahan dunia muslim, termasuk salah satunya ke Indonesia.

Di Indonesia proses reformasi pemikiran Islam, terjadi setelah terbukanya komunikasi yang luas dengan negara-negara Timur Tengah yang menjadi pusat Islam. Proses perubahan ini dilakukan oleh individu dan kelompok masyarakat yang ingin memperjuangkan identitas dan

${ }^{6}$ Dzofir, Zamakhsyari, "Pesantren dan Thariqah”, dalam Jurnal Dialog, Jakarta, Libang DEPAG RI, 19878, hlm. 10-12.

${ }^{7}$ Martin Van Bruinessen, Kitab Kuning Pesantren dan Tarekat, Bandung: Mizan, 1999, hlm. 7879

${ }^{8}$ Karel A. Steenbrink, Beberapa Aspek tentang Islam di Indonesia Abad ke-19, Jakarta, Bulan Bintang, 1984, hlm. 157.

${ }^{9}$ Murodi, M.A, Sejarah Kebudayaan Islam, (Semarang: Karya Toha Putra, tt), hlm. 195 hlm. 198

${ }^{10}$ Tatang M. Natsir, Di sekitar Reformasi dan Modernisasi Masyarakat Islam , Bandung: al-Maarif, 1972, 
prinsip ajaran Islam di tengah-tengah kehidupan bangsa Indonesia. Usaha tersebut direalisir antara lain dengan mendirikan organisasi kemasyarakatan tertentu. Di antara organisasi tersebut adalah organisasi Muhammadiyah. Sebuah organisasi Islam yang sangat berpengaruh selain NU di dalam sejarah Indonesia sejak awal Abad ke-19. Didirikan oleh K.H. Ahmad Dahlan yang berasal dari kampung kauman keraton Yogyakarta pada tanggal 18 Zulhijjah $1330 \mathrm{H}$, atau bertepatan dengan tanggal 18 Desember 1912. Ahmad Dahlan bernama kecil Muhammad Darwisy lahir pada tahun 1868 di Kampung Kauman Yogyakarta dan meninggal dunia pada tanggal 25 Febuari 1923 dalam usia 55 tahun. Ayahnya K.H. Abubakar bin K.H. Muhammad Sulaiman adalah pejabat Kepengulon Kesultanan Yogyakarta Hadiningrat dengan gelar Penghulu Katib di Mejid Besar Kesultanan. Sedang ibunya, Nyai Abubakar, adalah putri K.H. Ibrohim bin K.H. Hasan yang juga pejabat Kepengulongan Yogyakarta. ${ }^{11}$

Pada waktu muda K.H.A. Dahlan berkesempatan untuk ziarah dan bermukim di Mekah selama beberapa tahun. Kesempatan ini betul-betul ia pergunakan untuk meningkatkan kefaqihan ilmu agama dan memantapkan pendiriannya, menjalani hidup untuk konsisten menegakkan agama dan untuk memperbaiki kondisi umat Islam di tanah air. Selama di Mekkah ia berkenalan dengan pemikiran tokoh-tokoh pembaharu Islam pada masa itu. Atas pertolongan sahabatnya yang sudah lama menetap di Kota Mekkah, yaitu K.H. Baqir, Ahmad Dahlan bertemu dengan Syaikh Muhammad Rasyid Ridho. Pertemuannya dengan Rasyid Ridho di Mekkah telah dipergunakannya untuk belajar dan berdiskusi secara langsung tentang pembaharuan yang dilakukannya di Mesir dan lainnya. ${ }^{12}$

Selain berdiskusi dengan Rasyid Ridho dan ulama-ulama Mesir, Ahmad Dahlan juga gemar membaca majalah al-Manar dan Urwatul al-Wusqa yang berisi pemikiran pembaharuan Muhammad Abduh di Mesir. Bahkan Ahmad Dahlan juga belajar pada ulama sekaligus khatib Masjidil Haram dari tanah air Syeikh Ahmad Khatib al-Minangkabawi dari Minang Kabau, dan bersahabat dengan Kyai Nawawi (Banten), Kiyai Mas Abdullah (Surabaya), K.H. Faqih (Maskumambang). Selain itu ia juga belajar fiqih pada Syech Shaleh Bafedal, Syech Sa'id Yamani, ilmu Falak kepada Kyai Asy'ari Bawean, dan ilmu qiraah pada Syech Ali Misri Mekkah. 13

Di samping dalam bentuk organisasi kemasyarakatan gerakan modernisme Islam di Indonesia juga mewujudkan dirinya dalam bentuk gerakan pemikiran ilmiah para intelektual di

\footnotetext{
${ }^{11}$ M. Yunan Yusuf, et.al., Ensiklopedi Muhammadiyah, Jakarta: Raja Grafindo Persada dan Dikdasmen PP. Muhammadiyah, 2005, hlm. 73-74

${ }^{12}$ M. Yunan Yusuf, et. Al., Ibid, hlm. 72

${ }^{13}$ Muhammad Damami, Akar Gerakan Muhammadiyah, Yogyakarta: Fajar Pustaka Baru, 2000, hlm. 82. 
universitas-universita negeri seperti IAIN, UI, dll. Beberapa nama yang dikenal sebagai sebagai tokoh penggerak modernisme pemikiran islam tersebut seperti Harun Nasution, Deliar Noer, Mukti Ali, dll. Kerangka keilmuan yang dibangun oleh tokoh-tokoh pembaharuan, termasuk Harun Nasution pada dasarnya sama yaitu perubahan paradigma Islam tradisionalis menuju paradigma Islam rasionalis, dengan menawarkan prinsip-prinsip rasional atau rasionalitas (akal) yang telah diuji dalam sejarah pemikiran Islam abad klasik. Meskipun "jargon-jargon” yang digunakankan untuk menggambarkan pembaharuan pemikiran Islam berbeda-beda misalkan seperti Modernisasi Islam, kontektualisasi Islam, dan lainnya, sementara Harun Nasution menggunakan istilah "Islam Rasional", ${ }^{14}$ namun ide pembaharuan tersebut mengarah pada tujuan yang sama, yaitu perlunya mengkaji kembali ajaran Islam dengan menggunakan nalar rasional yang Islamis agar umat Islam mampu menjawab dan merespon perubahan globalisasi dan mampu mengerjar ketertinggalan.

Berdasarkan beberapa uraian tentang sejarah masuknya Islam sejak masa awal yaitu pada Abad ke-12 atau bahkan ada yang berpendapat sejak Abad ke-7 dapat kita simpulkan bahwa ajaran Islam yang masuk ke Indonesia termasuk dalam hal ini kota Palembang berasal dari berbagai belahan dunia (negara) asal Islam tumbuh berkembang lebih dahulu sehingga corak dan faham keislaman yang tumbuh dan berkembang di Indonesia pun sangat beraneka ragam (heterogen). Meskipun demikian faham keagamaan yang berkembang luas di Indonesia, termasuk kota Palembang saat ini adalah faham keagamaan yang secara fiqhiyah adalah menganut madzhab Syafi'i sedangkan secara kalam adalah mengikuti faham Ahlussunnah wa al-Jamaah alAsy'ariyah. ${ }^{15}$ Meskipun ada pendapat yang mengatakan bahwa madzhab Syi'ah dan Sunni Hanafi adalah mazdhab yang mula-mula dianut oleh umat Islam Indonesia, baru kemudian datang madzhab Syafi'i yang kemudian dianut oleh sebahagian besar penduduk Islam Nusantara dan juga madzhab Hambali yang direpresentasikan oleh gerakan kaum Paderi di Sumatera Barat yang datang pada masa berikutnya. ${ }^{16}$ Di sisi lain Syekh Abdussomad Al-Palimbani yang dikenal sebagai pengikut dan penyebar ajaran tarekat Samaniyah (yang dikenal luas pada zamannya) di Nusantara dan kota Palembang dikenal pula sebagai ulama yang berupaya mengembalikan kemurnian ajaran tasawuf al-Ghazali yang dikenal sebagai pengikut dan pengembang pemikiran kalam aliran Sunni. ${ }^{17}$

\footnotetext{
${ }^{14}$ Harun Nasution, Akal dan Wahyu dalam Islam, Jakarta: UI Press, 1986, hlm.52.

15 Ahmad Syafii Mufid, Paham Ahlu Sunnah wal Jamaah Dan Tantantangan Kontemporer Dalam Pemikiran dan Gerakan Islam di Indonesia,HARMONI, September-Desember 2013, hlm. 8

${ }^{16}$ Parlindungan dalam Ahmad Syafi'i Mufid, Ibid, hlm. 10

${ }^{17}$ Azyumardi Azra. Jaringan Ulama Timur Tengah dan Kepulauan Nusantara Abad XVIII. Bandung: Mizan, 1994, hlm. 250
} 


\section{Materi Dan Corak Pemikiran Kalam K.H.M. Zen Syukri}

Obyek pembahasan di dalam ilmu kalam sangat luas dan banyak antara lain mengenai fungsi akal dan wahyu, perbuatan Allah, free will dan predestination, sifat-sifat Allah, antropomorphise , dan lain sebagainya. Namun tidak semua obyek kajian dalam ilmu kalam itu dibahas di dalam buku "Risalatut Tauhid" yang ditulis oleh K.H.M. Zen Syukri. Berikut materi pemikiran kalam yang dikemukakan di dalam buku tersebut:

1) Free Will And Predestination

Sebagaimana telah kita ketahui bahwa konsep Free Will adalah faham tentang kebebasan/kemerdekaan manusia dalam menentukan perbuatanya dan Predestination (peran mutlak Tuhan terhadap perbuatan manusia) merupakan salah satu tema pokok yang menjadi perbincangan di dalam ilmu kalam. Yang menjadi pemasalahan dalam pembahasan ini adalah apakah manusia itu memiliki kebebasan di dalam menentukan perbuatan dan nasibnya atau sebaliknya bahwa perbuatan manusia itu telah ditakdirkan oleh Allah swt atau dengan kata lain manusia hanyalah sebagai alat untuk berlakunya perbuatan Tuhan.

Di dalam buku Risalatut Tauhid KH.M. Zen Syukri menjelaskan bahwa segala perbuatan hendaknya dipandang dengan mata fisik dan mata hati adalah adalah berasal dari Allah swt. ${ }^{18}$ Hal ini berdasarkan firman Allah swt:

"Dan Allah swt. menciptakan kamu dan apa yang kamu perbuat" (QS. AsShaffaat:96)

Untuk menguatkan pendapatnya K.H.M. Zen Syukri mengutip pendapat Sayyid Ali AlKhawas yang mengatakan bahwa mustahil manusia yang bersifat mumkin mengadakan sesuatu, segala perbuatan manusia pada hakekatnya hanyalah bekas/perbuatan Allah swt. Ketika seseorang melakukan shalat maka perbuatan shalat yang meliputi tegak, rukuk, sujud, bacaan2, dan lain-lain, semuanya itu adalah bekas dari Allah swt. Itulah yang dimaksud dengan La Haula wa laa quwwata illa billah. Meyakini bahwa hal itu adalah iradat dan kekuatan Allah yang ditolongkan-Nya kepada seorang hamba. ${ }^{19}$

Menjelaskan tentang atsar (bekas) perbuatan Allah pada makhluq Muhammad Zen Syukri mengumpamakan wayang yang dimainkan oleh sang dalang, maka segala sesuatu yang dilakukan dan dikehendaki oleh wayang pada hakikatnya adalah kehendak dan perbuatan

\footnotetext{
${ }^{18}$ Muhammad Zen Syukri, Risalatut Tauhid, hlm. hlm. 9. Risalah ini telah disyahkan oleh Al-Muhtarom Kyai Kemas Haji Abdul Roni Azhari Palembang dan telah diuraikan di masjid Agung Palembang pada tiap-tiap hari selasa di bulan Ramadhan tahun $1379 \mathrm{H}$

${ }^{19}$ Muhammad Zen Syukri, Ibid, hlm. hlm. 10
} 
dalang, wayang dalam hal ini berfungsi sebagai mazhar, tempat nyata perlakuan sang dalang saja. ${ }^{20}$ Kendati demikian Muhammad Zen Syukri pada penghujung penjelasannya mengatakan bahwa meskipun segala perbuatan itu sejatinya adalah perbuatan Allah swt, namun kita tidak boleh melampaui syari'at Nabi Muhammad saw, yaitu atas kita mengerjakan segala sesuatu yang diperintahkan Allah swt dan Rasul-Nya serta menjauhi segala larangan-Nya. Jangan sekali-kali gugur i'tiqad akan taklif syara'. Jika ada orang yang i'tiqad gugur taklif syara' maka mereka itu jatuh kepada kafir zindiq. ${ }^{21}$

Berdasarkan uraian Aba Zen Syukri tentang perbuatan manusia bahwa perbuatan manusia itu telah ditakdirkan oleh Allah swt atau dengan kata lain manusia hanyalah sebagai alat untuk berlakunya perbuatan Tuhan. Namun Aba Zen Syukri menjelaskan pula bahwa manusia harus berusaha untuk melaksanakan segala sesuatu yang diperintahkan oleh Allah swt dan Rasul-Nya. Jika seseorang hanya pasrah atau sengaja meniadakan niat untuk tidak melaksanakan perintah Allah swt dan Rasul-Nya maka dia digolongkan kafir zindiq. Pendapat Aba Zen Syukri tentang perbuatan manusia seirama dengan pandangan imam Asy'ari (aliran Ahlu al-Sunnah wa al-Jama'ah al-Asy'ariyah) dengan teori kasab yang berpendapat bahwa manusia memiliki dua perbedaan gerak.. Pertama, gerak yang bersifat paksaan tanpa dapat dielakkan (al-harakah al-idhthirariyyah). Gerakan ini datangnya dari luar diri manusia. Kedua, gerakan yang dikehendaki (al-harakah al-iradiyyah) yang datangnya berdasarkan usaha manusia. Pada gerakan yang pertama manusia tidak memiliki daya untuk mengelak atau memilih, sedangkan pada gerak yang kedua, manusia memunyai daya untuk memilih (ikhtiar). Pada gerak kedua inilah letak kasab manusia. Dalam kehidupan sehari-hari Aba Zen Syukri tidak mengabaikan kasab, berusaha sekuat tenaga baik dalam hal ibadah mahdlo ataupun dalam hal mu'amalah mencari rezeki, bermasyarakat dan lain sebagainya. Malam beliau manfaatkan taqarrub ila Allah, dengan zikir, tahajud, dan lain sebagainya. Siang beliau bekerja, berdakwah, mencari rezeki, bermasyarakat, dan seterusnya.

2) Perbuatan-perbuatan Tuhan

Sebagaimana telah disinggung pada Bab sebelumnya bahwa semua aliran dalam ilmu kalam berpendapat bahwa Allah swt juga melakukan perbuatan. Perbuatan di sini dipandang sebagai konsekuensi logis dari zat yang memiliki kemampuan untuk melakukan. Namun yang menjadi pertanyaan adalah apakah perbuatan Tuhan itu terbatas pada hal yang baik-baik saja atau tidak terbatas.

${ }^{20}$ Muhammad Zen Syukri, Ibid, hlm. hlm. 10
${ }^{21}$ Muhammad
${ }^{2}$ Zen Syukri, Ibid, hlm. hlm. 11 
Dalam masalah ini Muhammad Zen Syukri mengatakan bahwa amal dan perbuatan itu adalah cobaan dari Allah swt kepada hamba-Nya. Apabila seseorang melakukan perbuatan yang baik berarti dia sedang dicoba dengan kehendak Allah swt dan ridlo-Nya. Begitu juga apabila seseorang hamba sedang melakukan perbuatan yang jelek/jahat berupa kekufuran ataupun kemaksiatan itu berarti dia sedang dicoba dengan kehendak Allah swt dan murkaNya. ${ }^{22}$ Mengandung hikmah artinya segala sesuatu yang dikerjakan dan diciptakan Allah itu baik, meskipun menurut makhluk hal itu tidak baik namun sesungguhnya ada iktibar dan hikmah yang terkandung di balik ciptaan dan perbuatan-perbuatan Allah swt. tersebut.

Salah satu kejahatan kepada Allah swt apabila dia mengatakan bahwa segala yang baik adalah ketentuan Allah swt. sedangkan yang jahat adalah ketentuan oleh Iblis. Hal ini bertentangan dengan rukun iman yang enam bahwa yang baik dan jahat adalah iradat Allah (kehendak dan ketentuan Allah swt.) Lebih layak seseorang mengatakan bahwa perbuatan jahat disukai syaithan dan dimurkai Allah sedangkan perbuatan yang baik diridloi Allah swt dan Rasul-Nya. Sebagai contoh bunga mawar yang indah dan wangi aromanya tetapi disertai dengan duri yang tajam. Jika duri tersentuh oleh kita maka akan terasa sakit, tetapi bunga dan duri dikagumi orang, ditempatkan ditempat yang indah dan kadang-kadang dicium meski kadang duri dibuang. ${ }^{23}$ Oleh karena setiap perbuatan itu berasal dari Allah swt. dan baik pula maka Rasululllah saw. tidak pernah mendo'akan kafir-kafir Quraisy yang telah menyakiti beliau dengan kejahatan, karena memandang akan nisbah perbuatan itu kepada Allah swt. ${ }^{24}$

Meskipun segala ciptaan dan perbuatan Allah baik (mengandung hikmah) Allah swt., namun Aba Zen Syukri menolak orang yang berpendapat bahwa perbuatan baik dan perbuatan buruk adalah sama karena semuanya adalah dari Allah swt. Orang yang mengatakan demikian adalah berfaham jabariyah yang tergolong kafir zindiq karena hal tersebut bertentangan dengan misi risalah Islam yaitu membedakan antara yang jahat dengan yang baik. ${ }^{25}$

3) Sifat-sifat Allah swt (Tauhid Asma' wa al-Shifat)

Yang wajib dikenal oleh setiap orang akan Allah swt. ada dua puluh sifat Allah yang terbagi empat: ${ }^{26}$ sifat nafsiah, sifat salbiah, sifat ma'ani dan sifat ma'nawiah. Sifat nafsiah adalah al-Wujud (ada), adalah sifat yang wajib bagi zat Allah, sifat yang melazimkan akan adanya Allah swt yang adanya tidak disebabkan oleh zat yang lain. Sebagaimana firman Allah

${ }^{22}$ Muhammad Zen Syukri, Ibid, hlm. hlm. 9 hlm. 194-196

${ }^{23}$ Muhammad Zen Syukri, Cahaya di atas Cahaya (Nur 'ala Nur), Palembang: Percetakan Raden, 2008,

${ }^{24}$ Muhammad Zen Syukri, Ibid, hlm. hlm. 12

25 Syek Sayyid Abd. Rahman bin Muhammad bin Husin dalam Muhammad Zen Syukri, Cahaya di atas Cahaya (Nur 'ala Nur), Palembang: Percetakan Raden, 2008, hlm. 58

${ }^{26}$ Imam Asy'ari dalam Muhammad Zen Syukri Risalatut Tauhid, hlm. hlm. 19 
swt.:

"Akan kami (Allah) perlihatkan tanda-tanda kami di segenap penjuru alam dan di dalam diri mereka sendiri sehingga nyatalah bagi mereka bahwa Allah swt itu ada.” (QS.

Yang ke-dua adalah sifat salbiah, yaitu sifat jamal Allah artinya kesucian Allah atau untuk menolak sesuatu yang tidak patut bagi Allah swt. Sifat salbiah ada lima, yaitu: 1) Qidam (terdahulu), Allah adalah asal segala sesuatu dan tidak diadakan oleh sesuatu. Allah wujud qodim azali dan haqiqi mutlak, 2) Al-Baqa' (kekal), Baqa' Allah untuk menolak kesudahan bagi wujud Allah, Allah kekal selama-lamanya 3) Mukhalafatu lil hawadis (Berbeda dengan segala sesuatu) 4) Qiyamuhu bi nafsihi (Berdiri sendiri), artinya Allah itu tidak bergantung kepada selain Dia, berbeda dengan makhluk yang ada dan keberadaannya bergantung kepada Allah swt 5) Wahdaniat (esa), tidak berbilang, tiada sekutu bagi Allah swt.

Kemudian pembagian yang ke-tiga adalah sifat ma'ani, yaitu sifat kamal, sifat kesempurnaan Allah swt., yang terbagi tujuh: 1) Qudrat (kuasa) 2) Iradat (menentukan), 3) Ilmu (mengetahui) 4) Sama' (mendengar) 5) Bashar (melihat) 6) Kalam (berkata-kata) 7) hayyu (hidup). Untuk mengenal sifat ma'ani ini dapat diperoleh dengan memperhatikan kejadian alam semesta beserta segala yang ada di dalamnya. Memang jika kita melihat bendabenda alam dari bentuknya saja maka kita tidak akan melihat apa-apa (gelap) tetapi bila kita melihatnya dengan menggunakan ainulfikir (akal fikiran) dari segi iktibar maka akan nampaklah pada alam itu kesempurnaan qudrat iradat Allah swt, Nampak kebesaran dan kamal Allah. Seumpama kaca cermin kita dapat melihat atsar (bekas) dari sifat-sifat Allah swt. $^{27}$

Pembagian yang ke-empat adalah sifat ma'nawiyah atau sifat Qahar Allah swt, sifat ma'nawiyah adalah kelaziman dari sifat ma'ani, sifat ma'ani hanya dijalankan (dima'nawiahkan) itulah dinamakan Qahar Allah swt. Contoh ada orang yang kemarin masih sehat walafiat tetapi hari ini kita dengar kabar telah meninggal dunia. Maka pada saat itu hilanglah wujudnya oleh karena kehendak Allah swt., inilah yang disebut ma'nawiah atau Qahar Allah swt. Sifat ma'nawiah ada tujuh: Kaunuhu Taala Qadiran-Muridan, 'AlimanHayyan- Sami'an-Bashiran- Mutakalliman, artinya keadaan Allah ta'ala yang kuasa, keadaan Allah ta'ala yang menentukan, keadaan Allah Ta'ala yang mengetahui, keadaan Allah taala

${ }^{27}$ Muhammad Zen Syukri, Ibid, hlm. hlm. 25. Lihat juga Muhammad Zen Syukri, Cahaya di atas Cahaya, Palembang: Percetakan Raden, 2008, hlm. 200,. Muhammad Zen Syukri, Santapan jiwa, Palembang: UNSRI, 2000, hlm. 75 
yang hidup, keadaan Allah Taala yang mendengar, keadaan Allah Ta'ala yang mendengar, keadaan Allah Ta'ala yang melihat, keadaan Allah Ta'ala yang berkata-kata. ${ }^{28}$

\section{Sikap Masyarakat Kota Palembang Terhadap Pemikiran Kalam K.H.M. Zen Syukri}

Pada saat K.H. Muhammad Zen Syukri mengemukakan pemikiran tauhid atau pemikiran kalamnya melalui karya tulis dalam bentuk buku yang berjudul "Risalatut Tauhid" maka ada resistensi atau penolakan oleh para ulama dan kyai yang ada di kota Palembang terhadap faham keagamaan yang disampaikan Aba Zen Syukri di dalam kitab tersebut. Tidak kurang dari 17 orang tokoh kyai dan ulama yang menyampaikan ketidaksetujuan mereka terhadap faham keagamaan K.H.M. Zen Syukri tersebut. ${ }^{29}$

Menurut ustadzah Dr. Izzah Zen Syukri, M.Pd., hal itu terjadi karena karena adanya perbedaan pola fikir para ulama dan cendikiawan muslim dalam memahami ajaran agama Islam. Resistensi sebahagian para tokoh ulama dan kyai di kota Palembang terhadap faham keagamaan yang disampaikan oleh Aba Zen Syukri di dalam buku "Risalatut Tauhid" tersebut adalah pada pemaknaan tauhid yang diterjemahkan sebagai kekuasaan mutlak Allah swt yang seluas-luasnya terhadap seluruh aktifitas kehidupan dan tingkah laku (perbuatan) manusia. ${ }^{30}$ Bahwa segala perbuatan manusia pada hakekatnya hanyalah "atsar" atau perbuatan Allah swt. Sebagai contoh ketika seseorang melakukan shalat maka perbuatan shalat yang meliputi tegak, rukuk, sujud, bacaan-bacaan/doa, dan lain-lain, semuanya itu adalah bekas dari Allah swt. Dan itulah pula yang dimaksud dengan atau makna kalimat La Haula wa laa quwwata illa billah. Meyakini bahwa kesemuanya itu semata adalah iradat dan kekuatan Allah yang ditolongkan-Nya kepada seorang hamba.

Pemaknaan kalimat tauhid M. Zen Syukri tersebut berbeda dengan pemikiran-pemikiran kalam lainnya yang ada di Indonesia khususnya kota Palembang tentang perbuatan manusia. Pemikiran kalam dari kalangan rasionalis menempatkan free will dan kemerdekaan manusia dalam menentukan perbuatan dan nasibnya pada porsi yang lebih besar. Bahwa manusia itu sendiri yang menentukan nasib dan apa yang dia lakukan. Jika Allah swt. telah mematok nasib manusia berarti Allah swt. dzolim. ${ }^{31}$

Faham keagamaan (dalam bidang kalam) M. Zen Syukri tersebut juga mendapatkan kritik

\footnotetext{
${ }^{28}$ Muhammad Zen Syukri, Risalatut Tauhid, hlm. hlm. 25-26

29 Izzah Zen Syukri (Puteri K.H. Zen Syukri, Ketua Yayasan Pondok Pesantren Muqimussunnah), wawancara, Tanggal, 22 Juni 2019

${ }^{30}$ Izzah Zen Syukri (Puteri K.H. Zen Syukri, Ketua Yayasan Pondok Pesantren Muqimussunnah), wawancara, Tanggal, 22 Juni 2019

${ }^{31}$ Ris'an Rusli, Pemikiran Teologi Muhammad Natsir, Yogyakarta: Idea Press, 2012, hal. 168
} 
tajam dari para kyai dan ulama yang berasal dari kalangan Ahlu al-Sunnah wa al-Jamaah sebagai faham keagamaan (Islam) mayoritas yang ada di kota Palembang sehingga M. Zen Syukri tidak diperbolehkan menyampaikan pengajian (materi ceramah) di berbagai masjid dan mushola yang ada di kota Palembang, termasuk di masjid Agung Palembang lebih kurang selama 10 (sepuluh) tahun. ${ }^{32}$ Hal ini dapat dimaklumi karena di dalam aliran Ahlu al-Sunnah wa al-Jamaah sendiri terdapat dua kecenderungan atau corak pemikiran kalam, yaitu corak Asy'ariyah dan corak Maturidiah yang secara historis merujuk kepada pemikiran imam Hanafi. ${ }^{33}$ Corak Asy'ariyah lebih menegaskan kekuasaan mutlak Allah, sedangkan aliran Maturidiah memberikan ruang yang lebih besar kepada usaha manusia. ${ }^{34}$ Pada masyarakat kota Palembang waktu itu meskipun secara fiqih tidak terdapat perbedaan, sama-sama mengikuti faham atau madzhab Syafi'i, namun secara kalam penulis berpendapat bahwa pemikiran kalam Ahlu al-Sunnah wa al-Jamaah yang bercorak Maturidiah telah diikuti pula oleh sebahagian ulama/kyai yang ada di kota Palembang dengan indikasi adanya resistensi terhadap faham keagamaan (kalam) M. Zen Syukri yang menegaskan kekuasaan mutlak Allah swt. Bahwa segala perbuatan manusia pada hakekatnya hanyalah "atsar" atau perbuatan Allah swt.

\section{Internalisasi Pemikiran Kalam K.H.M. Zen Syukri di tengah Masyarakat Kota Palembang.}

Sebagaimana telah dikemukakan sebelumnya bahwa setelah kasus resistensi para kyai dan ulama kota Palembang terhadap ajaran Tauhid M. Zen Syukri berakhir justeru menimbulkan ketertarikan masyarakat, khususnya umat Islam kota Palembang terhadap ajaran keagamaan M. Zen Syukri tersebut. Tampaknya keputusan pengadilan dengan para saksi ahli tingkat nasional antara lain K.H. Abdul Karim Amrullah yang dikenal dengan sapaan Buya Hamka bahwa faham tauhid yang diajarkan oleh M. Zen Syukri bukanlah ajaran sesat sebagaimana yang disangkakan para ulama dan kyai kota Palembang dan dizinkan untuk menyampaikan faham keagamaannya, justeru menimbulkan animo masyarakat kota Palembang untuk mempelajari bagaimana sesungguhnya ajaran tauhid M. Zen Syukri. Animo masyarakat yang begitu tinggi untuk mengetahui ajaran M. Zen Syukri tersebut mengakibatkan ajaran keagamaan dan nama beliau semakin dikenal di tengah masyarakat kota Palembang. Aktifitas dakwah M. Zen Syukri yang kembali berjalan dan semakin meningkat intensitasnya serta pencetakan buku 'Risalatut Tauhid'

32 Izzah Zen Syukri (Puteri K.H. Zen Syukri, Ketua Yayasan Pondok Pesantren Muqimussunnah), wawancara, Tanggal, 22 Juni 2019 hlm. 178

${ }^{33}$ Harun Nasution, Teologi Islam: Aliran-aliran Sejarah Analisa Perbandingan, Jakarta: UI Press, 1986,

${ }^{34}$ Ris'an Rusli, Pemikiran Teologi Muhammad Natsir, Yogyakarta: Idea Press, 2012, hlm. 168 
yang memuat ajaran tauhid Aba Zen Syukri dalam skala besar karena minat masyarakat untuk membeli dan mempelajarinya, mengakibatkan perekonomian beliau meningkat pula di samping nama beliau yang semakin tersohor dan dimulyakan oleh masyarakat kota Palembang

Merupakan fenomena yang menarik. Bagaimana suatu pemikiran keagamaan yang pada awalnya mendapatkan kritikan yang pedas dan bahkan pemboikotan oleh kalangan ulama dan kyai kota Palembang sehingga M. Zen Syukri dilarang untuk menyampaikan pengajaran keagamaan, namun pada akhirnya diakui sebagai ajaran keagamaan yang syah bahkan sosok M. Zen Syukri kemudian menjadi figur yang disegani dan dihormati. Dikenal luas baik di kalangan umat Islam maupun non muslim

Dalam kaitannya dengan obyek penelitian, M. Zen Syukri mengeksternalisasikan faham keagamaannya, karena manusia (umat Islam) diperhadapkan pada ancaman-ancaman anomik dalam dunia yang merupakan hasil dari aktifitas manusia itu sendiri. ${ }^{35}$ Kondisi anomik tersebut setidaknya bersumber pada dua hal. Yang pertama kondisi anomik yang bersumber pada faham keagamaan yang menganggap bahwa manusia memiliki kekuasaan penuh untuk menentukan perbuatan dan nasibnya. Faham keagamaan yang seperti itu menurut M. Zen Syukri dapat menjerumuskan manusia kepada syirik khafi, ${ }^{36}$ karena segala sesuatu yang ada pada diri manusia pada hakekatnya adalah titipan Allah, bukan milik kita, termasuk daya dan upaya yang kita miliki untuk melakukan sesuatu adalah berasal dari Allah swt., La hawla wa laa quwwata illa billah. Orang yang mengaku bahwa ibadah yang dia lakukan atau kesuksesan hidup yang dia capai adalah semata-mata karena hasil kerja kerasnya dan terlepas dari peran Allah swt. maka dia telah terjerumus kepada syirik khafi, menyekutukan Allah swt. dengan diri sendiri karena merasa dirinya memiliki sifat ketuhanan. Kondisi anomik yang kedua berada pada dataran kehidupan masyarakat kota Palembang dengan modernitas sebagai ciri khas kehidupan masyarakat kota meski modernitas itu cenderung mengabaikan hal-hal yang bersifat spiritual dan membawa manusia kepada pola hidup materialistik dan hedonistik. Kehidupan masyarakat kota lebih didominasi oleh pandangan kepentingan ekonomi dan politik serta tidak mempertimbangkan kenyataan lain seperti nilai-nilai budaya, termasuk kepercayaan keagamaan. Padahal segala sesuatu yang non material adalah juga kenyataan yang menjadi bagian penting dalam kehidupan masyarakat. Kondisi kehidupan masyarakat yang seperti itu menurut M. Zen Syukri harus dibenahi karena tidak sesuai dengan ajaran Islam dan mengakibatkan kehidupan sosial yang tidak teratur (anomik). Tujuan hidup yang terlalu mementingkan materi mengakibatkan masyarakat kota

\footnotetext{
35 Peter L. Berger, The Sacred Canopy (Elements Of Sosiological Theory Of Religion), New York: Doubleday \& Company, Inc. Garden City, 1967 , hlm. 29

${ }^{36}$ Muhammad Zen Syukri, Melepaskan Diri dari bahaya Syirik, Jakarta: Azhar, 2009, hlm. 59
} 
terjebak pada pola kehidupan yang menghalalkan segala cara dalam mencari rezeki tanpa mempertimbangkan faktor keberkahan, menghamburkan-hamburkan materi pada hal-hal yang kurang bermanfaat bahkan dilarang agama (hedonistik) seperti mengkonsumsi narkoba (narkotika dan obat-obatan), dan lain sebagainya. Di sisi lain kehidupan masyarakat kota yang lebih didominasi oleh pandangan kepentingan ekonomi serta tidak mempertimbangkan kenyataan lain seperti nilai-nilai budaya, termasuk kepercayaan keagamaan mengakibatkan masyarakat lambat laun mengalami kehausan spiritual dan mudah terserang stress yang pada akhirnya dapat berdampak pula terhadap kesehatan jasmani ketika terjadi kesenjangan antara harapan dan realita yang mereka hadapi. Pada titik inilah masyarakat kota yang telah terdampak faham materialistik dan hedonistik membutuhkan solusi yang dapat mengatasi problematika psikis dan non-psikis yang tengah melanda kehidupan mereka

Proses eksternalisasi ${ }^{37}$ faham keagamaan atau pemikiran kalam M. Zen Syukri sehingga menjadi suatu entitas yang eksis di dalam kehidupan masyarakat kota Palembang disampaikan, diuraikan secara jelas dan gamblang melalui pengajian-pengajian/cawisan dan majelis zikir yang beliau bina. Selain itu materi-materi keagamaan M. Zen Syukri disampaikan pula melalui media cetak dengan menerbitkan buku-buku yang ditulis oleh beliau sendiri. Tentu ada banyak faktor yang menunjang keberhasilan dakwah M. Zen Syukri. Namun kesabaran, sikap toleran dan lemah lembut menjadi faktor penting keberhasilan M. Zen Syukri di dalam menyampaikan risalah dakwahnya. M. Zen Syukri tidak hanya berusaha menguasai ilmu nabi tetapi berusaha juga meneladani sikap/sifat nabi saw. termasuk dalam hal menyampaikan ajaran Islam (dakwah), ${ }^{38}$ sehingga beliau pada paruh akhir masa perjuangan dakwahnya menjadi sosok yang fenomenal, sangat dihormati dan dicintai oleh berbagai kalangan. Hal ini sesuai dengan ajaran Islam, sebagaimana firman Allah swt.:

"Maka disebabkan rahmat dari Allah-lah kamu bersikap lemah lembut kepada mereka. Sekiranya kamu bersikap keras lagi berhati kasar, tentulah mereka menjauhkan dari

\footnotetext{
${ }^{37}$ Peter L. Berger menggunakan konsep eksternalisasi untuk mengungkapkan bahwa manusia adalah mahluk hidup yang secara terus menerus mencurahkan, mengungkapkan, mengekspresikan dirinya ke dalam dunia sekelilingnya, baik itu dalam bentuk aktivitas fisik maupun mental. Menurut Berger, eksternalisasi diri manusia ke dalam dunia sekelilingnya merupakan suatu keharusan antropologis karena homosapiens menempati posisi yang istimewa karena memiliki keistimewaan dalam hubungan dengan dirinya sendiri dan maupun dengan lingkungan atau dunia disekelilingnya. Tidak seperti binatang menyusui tingkat tinggi lainnya, yang dilahirkan dengan kondisi organisme yang pada pokoknya sudah lengkap, manusia sebaliknya "belum selesai" ketika dia dilahirkan. Lebih lanjut penjelasan tentang konsep eksternalisasi dapat dibaca dalam buku Peter L. Berger, Langit Suci, Jakarta: LP3ES, 1991, hlm. 5 dan "Tafsir Sosial atas Kenyataan: Risalah tentang Sosiologi Pengetahuan".

38 Izzah Zen Syukri (Puteri K.H. Zen Syukri, Ketua Yayasan Pondok Pesantren Muqimussunnah), wawancara, Tanggal, 4 November 2018
} 
Tamaddun: Jurnal Kebudayaan dan Sastra Islam, Vol. XVIII No. 2, 2018|

sekelilingmu. Karena itu maafkanlah mereka, mohonkanlah ampun bagi mereka dan bermusyawarahlah dengan mereka dalam urusan itu. Kemudian apabila kamu telah membulatkan tekad maka bertawakkallah kepada Allah. Sesungguhnya Allah menyukai orang-orang yang bertawakkl kepada-Nya (Ali Imron:159) .”

Di samping itu keberhasilan M. Zen Syukri dalam mengeksternalisasi faham atau ajaran keagamaannya itu menurut penulis ditunjang oleh kondisi sosiologis (sosial keagamaan) masyarakat kota Palembang bahwa faham keagamaan yang berkembang luas di Indonesia dalam hal ini termasuk kota Palembang adalah faham keagamaan yang secara fiqhiyah adalah menganut madzhab Syafi'i sedangkan secara kalam adalah mengikuti faham Ahlu al-Sunnah wa al-Jamaah al-Asy'ariyah. Jadi ada relevansi faham keagamaan M. Zen Syukri dengan kondisi sosial keagamaan masyarakat kota Palembang. Karena kondisi sosiologis yang seperti itu tentunya memudahkan M. Zen Syukri di dalam menyampaikan ajaran-ajarannya karena beliau sendiri mengikuti faham ahlu al-Sunnah wa al-Jama'ah dan beliau adalah murid langsung dari K.H. Hasyim Asy'ari pendiri ormas NU (Nahdlatul Ulama) yang di dalam Anggaran Dasar organisasinya menegaskan bahwa NU secara pemikiran kalam adalah beraliran Ahlu al-Sunnah wa al-Jamaah al-Asy'ariyah, dan secara fiqih adalah mengikuti mazhab Syafi'i.

Di sisi lain K.H. Muhammad Zen Syukri adalah pengikut dan pengembang tarikat Samaniyah, sebuah tarikat sufi yang berkembang luas di wilayah Sumatera Selatan khususnya kota Palembang sejak dahulu kala. Sebagaimana kita ketahui bahwa ajaran tasawuf tarikat Samaniyah sudah masuk ke Palembang sejak zaman penjajahan Belanda yang dibawa oleh seorang ulama yang terkenal antara lain Abdul Shamad Al-Palimbani yang kemudian dilanjutkan oleh keturunan dan murid-murid beliau seperti Syeikh Muhammad Aqib Ibn Kgs. Hasan al Din (1736-1818M), Muhammad Muhyi al-Din al-Palimbani dan Kemas Muhammad Ibn Ahmad Al-Palimbani, dll $^{39}$ Hal ini tentu memberikan kemudahan pula bagi M. Zen Syukri di dalam menyampaikan ajaran keagamaannya.

\section{PENUTUP}

Pemikiran Kalam K.H. Muhammad Zen Syukri adalah bercorak aliran kalam Ahlu al-Sunnah wa al-Jama'ah al-Asy'ariyyah. Terdapat relevansi antara pemikiran kalam K.H. Muhammad Zen Syukri dengan kondisi sosiologis masyarakat kota Palembang karena secara sosial keagamaan

39 Zulkifli Dan Karim Nasution, Islam Dalam Sejarah Dan Budaya Masyarakat Sumatera Selatan, Palembang: Universitas Sriwijaya, 2001, hlm. 74 
faham keagamaan Ahlu al-Sunnah wa al-Jama'ah al-Asy'ariyah yang disampaikan oleh K.H.M. Zen Syukri telah dikenal dan diikuti oleh sebahagian besar masyarakat kota Palembang sejak lama. Sehingga ajaran dan faham keagamaan K.H. Muhammad Zen Syukri dapat diterima masyarakat kota Palembang dengan baik, meskipun sebelumnya terjadi resistensi oleh sebahagian ulama yang berada di kota Palembang.

\section{DAFTAR PUSTAKA}

\section{Buku Sumber:}

Suharsimi Arikunto, Prosedur Penelitian (Suatu Pendekatan Praktik), Jakarta: PT. Rineka Cipta, 2010.

M Sayuthi Ali, Metodologi Penelitian Agama: Pendekatan Teori Dan Praktek, Jakarta: PT. RajaGrafindo, 2002.

Moh Nazir, Metodologi Penelitian, Jakarta: Ghalia Indonesia, 2005.

G.E. Marrison, The Coming of Islam to the east Indies, JBRAS Vol. 24, no. 1 (1951).

Dzofir, Zamakhsyari, "Pesantren dan Thariqah", dalam Jurnal Dialog, Jakarta, Libang DEPAG RI, 1987. 1999.

Martin Van Bruinessen, Kitab Kuning Pesantren dan Tarekat, Bandung: Mizan,

Karel A. Steenbrink, Beberapa Aspek tentang Islam di Indonesia Abad ke-19, Jakarta, Bulan Bintang, 1984.

Murodi, M.A, Sejarah Kebudayaan Islam, (Semarang: Karya Toha Putra, tt).

Tatang M. Natsir, Di sekitar Reformasi dan Modernisasi Masyarakat Islam , Bandung: alMaarif, 1972.

M. Yunan Yusuf, et.al., Ensiklopedi Muhammadiyah, Jakarta: Raja Grafindo Persada dan Dikdasmen PP. Muhammadiyah, 2005. 2000.

Muhammad Damami, Akar Gerakan Muhammadiyah, Yogyakarta: Fajar Pustaka Baru,

Harun Nasution, Akal dan Wahyu dalam Islam, Jakarta: UI Press, 1986.

Ahmad Syafii Mufid, Paham Ahlu Sunnah wal Jamaah Dan Tantantangan Kontemporer Dalam Pemikiran dan Gerakan Islam di Indonesia,HARMONI, September-Desember 2013.

Azyumardi Azra. Jaringan Ulama Timur Tengah dan Kepulauan Nusantara Abad XVIII. Bandung: Mizan, 1994.

Muhammad Zen Syukri, Risalatut Tauhid, hlm. hlm. 9. Risalah ini telah disyahkan oleh AlMuhtarom Kyai Kemas Haji Abdul Roni Azhari Palembang dan telah diuraikan di masjid Agung Palembang pada tiap-tiap hari selasa di bulan Ramadhan tahun $1379 \mathrm{H}$

Muhammad Zen Syukri, Santapan jiwa, Palembang: UNSRI, 2000, hlm. 75 168

Ris'an Rusli, Pemikiran Teologi Muhammad Natsir, Yogyakarta: Idea Press, 2012, hal.

Harun Nasution, Teologi Islam: Aliran-aliran Sejarah Analisa Perbandingan, Jakarta: UI Press, 1986

Ris'an Rusli, Pemikiran Teologi Muhammad Natsir, Yogyakarta: Idea Press, 2012

Peter L. Berger, The Sacred Canopy (Elements Of Sosiological Theory Of Religion), New York: Doubleday \& Company, Inc. Garden City, 1967.

Muhammad Zen Syukri, Melepaskan Diri dari bahaya Syirik, Jakarta: Azhar, 2009. 


\section{Sumber Internet:}

https://cendikiasumsel wordpress.com

http://kbbi.web.id, KBBI online

Sriwijaya Post, Kiai Sepuh Berpulang, Jumat, tanggal 23 Maret 2012, hal.1. http://issuu.com/sripoku /docs/23032012/7

\section{Nara Sumber :}

Izzah Zen Syukri (Puteri K.H. Zen Syukri, Ketua Yayasan Pondok Pesantren Muqimussunnah), wawancara, Tanggal, 4 November 2018.

Izzah Zen Syukri (Puteri K.H. Zen Syukri, Ketua Yayasan Pondok Pesantren Muqimussunnah), wawancara, Tanggal, 26 Mei 2019

Izzah Zen Syukri (Puteri K.H. Zen Syukri, Ketua Yayasan Pondok Pesantren Muqimussunnah), wawancara, Tanggal, 22 Juni 2019

H. Syaiful Anwar (Sahabat/Murid, Pembina jama'ah pengajian K.H.M. Zen Syukri), wawancara, Tanggal, 28 Juli 2019

Kgs. H.M. Sayuti (Sahabat/Murid, Pembina jama'ah pengajian K.H.M. Zen Syukri), wawancara, Tanggal, 28 Juli 2019

K.H. Zainal Abidin Hanif, (Sahabat, Pembina jama'ah pengajian K.H.M. Zen Syukri), wawancara, Tanggal, 28 Juli 2019 